\title{
THE STUDY OF ADSORPTION ON Cr(VI) IN NATURAL CLAY SURFACE MODIFIED WITH SURFACTANT CTAB (Cetyltrimethylammonium Bromide)
}

\author{
Maksum, Susi Nurul Khalifah, Anton Prasetyo \\ Jurusan Kimia, Fakultas Sains dan Teknologi, UIN Maulana Malik Ibrahim Malang
}

\begin{abstract}
Clay is a mineral particles composed of silica-alumina base frame, has a layered structure and a hollowed space causing surface becomes very widespread and effective as an adsorbent. Adsorbent of clay is very effective to adsorb cation for having negatively charged surfaces, but its ability to adsorb anion is very low, such as $\mathrm{Cr}(\mathrm{VI})$ formed in $\mathrm{HCrO}_{4}^{-}$at $\mathrm{pH}$ 2. This research has been conducted in the clay of activation process chemically with the variation of $\mathrm{H}_{2} \mathrm{SO}_{4}$ 0,5, 1,0, 1,5 and 2,0 $\mathrm{M}$ and physically with the variation in the temperature of $200,300,400^{\circ} \mathrm{C}$ as well as modifying the surface with the variation of CTAB surfactant 25, 50, 75 , and $100 \mathrm{mM}$ to enhance the adsorption of $\mathrm{Cr}(\mathrm{VI})$. The results of study showed that the treatment on the activation and modification of natural clay can increase the adsorption capacity of $\mathrm{Cr}(\mathrm{VI})$ is greater. Adsorption capacity (Qe) before activating the natural clay is $0,0971 \mathrm{mg} / \mathrm{g}$, while the Na-clay increased adsorption of $\mathrm{Cr}(\mathrm{VI})$ at 7,85 \% as indicated by Qe $=0,1756 \mathrm{mg} / \mathrm{g}$ of natural clay. The use of 0,5 $\mathrm{M} \mathrm{H}_{2} \mathrm{SO}_{4}$ activation of adsorption increased by $21,44 \%$ to the value of $Q e=0,3115 \mathrm{mg} / \mathrm{g}$. The treatment of physically activation after activating the best chemical showed at a temperature of $200^{\circ} \mathrm{C}$ with an increase of $29,82 \%$ adsorption of value $Q e=0,3953 \mathrm{mg} / \mathrm{g}$. While modification to the clay treatment results in the best physical activation get CTAB 25 $\mathrm{mM}$ concentration with increased adsorption of 94,54\% with a value of Qe $=1,0425 \mathrm{mg} / \mathrm{g}$.
\end{abstract}

Keywords: Natural clay, Activation, Modification, Adsorption of $\mathrm{Cr}(\mathrm{VI})$

\section{ABSTRAK}

Lempung merupakan partikel mineral yang tersusun dari kerangka dasar silika-alumina, memiliki struktur yang berlapis dan berongga sehingga menyebabkan permukaannya menjadi sangat luas dan efektif sebagai adsorben. Adsorben dari lempung sangat efektif untuk mengadsorpsi kation karena memiliki permukaan yang bermuatan negatif, tetapi kemampuannya untuk mengadsorpsi anion sangat rendah, seperti $\mathrm{Cr}(\mathrm{VI}) \mathrm{yang}$ terbentuk dalam $\mathrm{HCrO}_{4}^{-}$pada $\mathrm{pH}$ 2. Penelitian ini telah dilakukan proses aktivasi lempung secara kimia dengan variasi $\mathrm{H}_{2} \mathrm{SO}_{4}$ 0,5; 1,0;1,5 dan 2,0 $\mathrm{M}$ dan aktivasi fisika dengan variasi suhu 200, 300, $400{ }^{\circ} \mathrm{C}$ serta memodifikasi permukaannya dengan surfaktan CTAB dengan variasi surfaktan CTAB 25; 50; 75; dan $100 \mathrm{mM}$ untuk meningkatkan daya adsorpsi $\mathrm{Cr}(\mathrm{VI})$. Hasil penelitian menunjukkan bahwa adanya perlakuan aktivasi dan modifikasi pada lempung alam dapat meningkatkan kemampuan adsorpsi Cr(VI) lebih besar. Kapasitas adsorpsi (Qe) lempung alam sebelum diaktivasi yaitu $0,0971 \mathrm{mg} / \mathrm{g}$, sedangkan Na-lempung mengalami peningkatan adsorpsi $\mathrm{Cr}(\mathrm{VI})$ sebesar 7,85 \% yang ditunjukkan dengan Qe $=0,1756 \mathrm{mg} / \mathrm{g}$ dari lempung alam. Penggunaan aktivasi $\mathrm{H}_{2} \mathrm{SO}_{4}$ 0,5 M mengalami peningkatan adsorpsi sebesar 21,44\% dengan nilai Qe $=0,3115 \mathrm{mg} / \mathrm{g}$. Perlakuan aktivasi fisika setelah diaktivasi kimia terbaik ditunjukkan pada suhu $200{ }^{\circ} \mathrm{C}$ dengan peningkatan adsorpsi sebesar $29,82 \%$ yang bernilai Qe $=0,3953 \mathrm{mg} / \mathrm{g}$. Sedangkan perlakuan modifikasi pada lempung hasil aktivasi fisika terbaik didapatkan konsentrasi CTAB $25 \mathrm{mM}$ dengan peningkatan adsorpsi sebesar $94,54 \%$ dengan nilai Qe $=1,0425 \mathrm{mg} / \mathrm{g}$.

Kata Kunci: Lempung alam, Aktivasi, Modifikasi, Adsorpsi Cr(VI)

\section{PENDAHULUAN}

Indonesia mempunyai bahan alam berupa tanah lempung yang sangat melimpah, salah satunya di Kecamatan Gandusari Kabupaten Trenggalek yang telah dimanfaatkan oleh masyarakat sekitar sebagai bahan pembuatan genteng. Selain digunakan sebagai pembuatan genteng, lempung juga dapat digunakan sebagai adsorben yang ekonomis dengan kapasitas adsorpsi yang besar. Hal ini disebabkan karena lempung memiliki luas permukaan yang tinggi, stabil secara kimia, struktur permukaan yang bervariasi, kapasitas 
pertukaraan ion yang tinggi serta adanya asam-asam Bronsted dan Lewis (Bhattacharyya dan Gupta, 2006).

Aplikasi lempung sebagai adsorben banyak digunakan sebagai bahan alternatif untuk mengatasi permasalahan limbah, terutama limbah logam berat seperti kromium. Kromium biasanya banyak berasal dari industri pelapisan logam, penghambat korosi besi, penyamakan kulit, cat, tekstil dan bahan pengawet kayu (Patri, 2012). Kromium yang stabil dalam perairan dapat ditemukan sebagai $\mathrm{Cr}$ (III) yang berbentuk senyawa kationik $\left(\mathrm{Cr}^{3+}\right)$ dan $\mathrm{Cr}(\mathrm{VI})$ berbentuk anionik seperti $\mathrm{HCrO}_{4}^{-}, \mathrm{CrO}_{4}{ }^{2-}$ dan $\mathrm{Cr}_{2} \mathrm{O}_{7}{ }^{2-}$ (Cotton dan Wilkinson, 1989). Logam $\mathrm{Cr}(\mathrm{VI})$ lebih bersifat toksik, memiliki kelarutan yang sangat tinggi, korosif dan karsinogenik daripada logam Cr(III) (Patri, 2011).

Kemampuan lempung untuk mengadsorpsi anion seperti $\mathrm{Cr}(\mathrm{VI})$ sangat rendah, karena lempung memiliki permukaan yang bermuatan negatif. Beberapa metode telah dikenal untuk meningkatkan kemampuan adsorpsi lempung yaitu dengan aktivasi kimia dan aktivasi fisika serta memodifikasi permukaan lempung.

Pada penelitian ini telah dilakukan aktivasi kimia dengan menggunakan variasi $\mathrm{H}_{2} \mathrm{SO}_{4}$ dan aktivasi fisika dengan variasi pemanasan pada suhu tinggi dan juga telah dilakukan modifikasi permukaannya dengan variasi CTAB untuk meningkatkan kemampuan adsorpsi lempung terhadap $\mathrm{Cr}(\mathrm{VI})$.

Penambahan konsentrasi CTAB dilakukan diatas CMC (critical micelle concentration) agar dapat mengubah permukaan lempung yang bermuatan negatif menjadi bermuatan positif, sehingga kemampuan lempung dalam mengadsorpsi $\mathrm{Cr}(\mathrm{VI})$ yang berupa anionik akan lebih besar. Selanjutnya dilakukan perbandingan kemampuan adsorpsi dari masing masing lempung alam, $\mathrm{Na}-$ lempung, Na-lempung teraktivasi kimia dan fisika serta Na-lempung termodifikasi permukaannnya dengan CTAB.

\section{METODE PENELITIAN}

Penelitian ini terdiri dari beberapa tahapan, yaitu benefisiasi, preparasi sampel, preparasi Na-lempung, aktivasi Na-lempung, Modifikasi permukaan lempung hasil aktivasi dengan surfaktan CTAB dan penentuan $\mathrm{Cr}(\mathrm{VI})$ dengan metode spektrofotometri UV-Vis serta karakterisasi dengan FTIR.

\section{Benefisiasi}

Lempung alam dikeringkan pada suhu kamar, lalu ditumbuk dan dilarutkan dengan akuades. Campuran diaduk sampai semua lempung larut dan dibiarkan beberapa hari sampai lempung membentuk tiga bagian. Bagian paling atas merupakan senyawa organik dan garam-garam terlarut dalam air. Bagian tengah merupakan lempung, sedangkan bagian paling bawah merupakan kerikil, pasir dan pengotor lainnya yang memiliki berat jenis yang tinggi. Hasil lempung yang diperoleh diulangi lagi untuk mendapatkan pemisahan yang sempurna. Setelah itu, hasil benefisiasi dikeringkan di bawah sinar matahari (Abdulloh, 2004).

\section{Preparasi Sampel}

Fraksi lempung yang sudah kering ditumbuk sampai menjadi serbuk, kemudian diayak dengan ayakan 200 mesh. Selanjutnya lempung alam dikarakterisasi dengan FTIR.

\section{Preparasi Na-Lempung}

Sebanyak 100 gr lempung dimasukkan ke dalam $1000 \mathrm{~mL} \mathrm{NaCl} 1 \mathrm{M}$ dan diaduk selama 24 jam pada suhu $70-80{ }^{\circ} \mathrm{C}$. Residu dimasukkan ke $1000 \mathrm{~mL} \mathrm{NaCl} 6 \mathrm{M}$ sambil diaduk selama 24 jam. Residu dicuci dengan aquades untuk menghilangkan sisa ion klorida. Filtrat diuji dengan larutan $\mathrm{AgNO}_{3} \quad 1 \quad \mathrm{M}$ sampai tidak terbentuk endapan putih $\mathrm{AgCl}$. Lempung yang telah bebas ion klorida selanjutnya dikeringkan dalam oven pada suhu $100{ }^{\circ} \mathrm{C}$ selama 24 jam (Wijaya, dkk., 2005 dalam Patri, 2012).

\section{Aktivasi Na-Lempung}

Na-Lempung diaktivasi secara kimia dengan cara ditimbang masing-masing sebanyak 5 gr dan dimasukkan ke dalam 4 
buah erlenmeyer $250 \mathrm{~mL}$. Kemudian ditambahkan $100 \quad \mathrm{~mL} \quad \mathrm{H}_{2} \mathrm{SO}_{4}$ dengan variasi konsentrasi 0,$5 ; 1,0 ; 1,5 ;$ dan $2,0 \mathrm{M}$ (Suarya, 2008) sambil diaduk selama 5 jam (Akar, dkk., 2009). Campuran disaring dan dicuci dengan air panas $\left(60-70{ }^{\circ} \mathrm{C}\right)$ sampai terbebas dari ion sulfat yang ditandai dengan tidak terbentuknya endapan putih $\mathrm{BaSO}_{4}$ (tes negatif terhadap $\mathrm{BaCl}_{2}$ ) (Suarya, 2008). Selanjutnya dilakukan adsorpsi terhadap $\mathrm{Cr}(\mathrm{VI})$.

Hasil aktivasi lempung secara kimia dilanjutkan ke aktivasi fisika yaitu dengan cara sampel dikeringkan dalam tanur pada variasi suhu 200; 300; dan $400{ }^{\circ} \mathrm{C}$ selama 6 jam (Akar, dkk., 2009), lalu disimpan dalam desikator. Selanjutnya dilakukan adsorpsi terhadap $\mathrm{Cr}(\mathrm{VI})$.

\section{Modifikasi Permukaan Lempung Hasil Aktivasi dengan Surfaktan CTAB}

Sebanyak 2 gram sampel hasil aktivasi fisika terbaik ditambahkan $100 \mathrm{~mL}$ CTAB dengan variasi konsentrasi 25; 50; 75 dan $100 \mathrm{mM}$ dan diaduk dalam shaker pada suhu ruang selama 4 jam dengan kecepatan 200 rpm. Suspensi yang dihasilkan disaring dan dicuci dengan $100 \mathrm{~mL}$ akuades sebanyak 2 kali. Hasil lempung modifikasi dikeringkan pada suhu kamar (Plaska, dkk., 2012). Selanjutnya dilakukan adsorpsi terhadap $\mathrm{Cr}(\mathrm{VI})$.

\section{Penentuan $\mathrm{Cr}(\mathrm{VI})$ dengan Metode Spektrofotometri}

Larutan $\mathrm{Cr}$ (VI) 20 ppm sebanyak 50 $\mathrm{mL}$ dikondisikan pada $\mathrm{pH} 2$ dengan menggunakan $\mathrm{H}_{2} \mathrm{SO}_{4} 0,1 \mathrm{M} / \mathrm{NaOH} 0,1$ $\mathrm{M}$, lalu ditambahkan $3 \mathrm{~mL}$ larutan buffer $\mathrm{pH}$ 2. Kemudian sebanyak 0,5 gr lempung alam dimasukkan ke dalam erlenmeyer 250 $\mathrm{mL}$, lalu ditambahkan larutan $\mathrm{Cr}(\mathrm{VI})$ sebanyak $25 \mathrm{~mL}$. Campuran dishaker selama 30 menit dengan kecepatan 200 rpm pada suhu ruang $25^{\circ} \mathrm{C}$.

Campuran yang didapat kemudian disaring dengan kertas saring. Filtrat yang diperoleh dipipet $5 \mathrm{~mL}$ dan dimasukkan dalam beaker glass yang dikondisikan pada $\mathrm{pH} 2$ dengan menggunakan $\mathrm{H}_{2} \mathrm{SO}_{4} 0,1 \mathrm{M} /$ $\mathrm{NaOH}$ 0,1 M. Lalu ditambahkan $3 \mathrm{~mL}$ 49 larutan buffer $\mathrm{pH} 2$ dan ditambahkan $2 \mathrm{~mL}$ larutan difenilkarbazida $(0,25 \%)$. Setelah itu, dimasukkan ke dalam labu ukur $25 \mathrm{~mL}$ dan diencerkan sampai tanda batas dengan akuades. Larutan didiamkan 5-10 menit. Kemudian absorbansinya diukur dengan spektrofotometer UV-Vis pada panjang gelombang $540 \mathrm{~nm}$.

Prosedur diatas diulangi lagi untuk adsorpsi $\mathrm{Cr}(\mathrm{VI})$ pada Na-lempung, Nalempung teraktivasi kimia dengan variasi konsentrasi 0,$5 ; 1,0 ; 1,5$; dan $2,0 \mathrm{M}, \mathrm{Na}-$ lempung teraktivasi fisika dengan variasi suhu 200; 300; dan $400{ }^{\circ} \mathrm{C}$, serta termodifikasi permukaan lempung hasil aktivasi dengan variasi konsentrasi CTAB 25; 50; 75 dan $100 \mathrm{mM}$.

Konsentrasi ion logam dihitung dengan menggunakan kurva standar. Selisih konsentrasi awal dan akhir dari larutan $\mathrm{Cr}(\mathrm{VI})$ merupakan jumlah $\mathrm{Cr}(\mathrm{VI})$ yang dapat diadsorpsi oleh lempung. Selanjutnya kapasitas adsorpsi dapat dihitung dengan persamaan (Akar, dkk., 2009):

$$
Q e=\frac{\left(C_{0}-C_{e}\right) V}{m}
$$

Dimana Qe adalah kapasitas adsorpsi per bobot lempung $(\mathrm{mg} / \mathrm{g}), \mathrm{V}$ adalah volume larutan (L), $\mathrm{C}_{\mathrm{o}}$ adalah konsentrasi awal larutan (ppm), $\mathrm{C}_{\mathrm{e}}$ adalah konsentrasi akhir larutan (ppm), $\mathrm{m}$ adalah massa lempung (g).

\section{Karakterisasi FTIR (Fourier Transform Infrared) \\ FTIR digunakan untuk} mengidentifikasi keberadaan gugus-gugus fungsional utama di dalam struktur senyawa seperti lempung. Pada penelitian ini lempung alam, Na-lempung, Nalempung teraktivasi kimia terbaik, Nalempung teraktivasi fisika terbaik dan $\mathrm{Na}$ lempung termodifikasi CTAB dikarakterisasi dengan menggunakan sinar inframerah. Spektrum inframerah direkam menggunakan spektrofotometer Fourier Transform Infrared (FTIR) dengan metode pelet $\mathrm{KBr}$ pada daerah 4000-400 $\mathrm{cm}^{-1}$ (Khenifi, dkk., 2007). 


\section{HASIL DAN PEMBAHASAN}

Lempung alam yang digunakan dalam penelitian ini berasal dari daerah Gandusari Kabupaten Trenggalek yang telah dianalisis XRD oleh Mukhlisin (2013) dan didapatkan hasil bahwa lempung alam terdiri dari banyak komponen diantaranya yang banyak ditemukan yaitu chloritoid, feldspar, kyanite, potassium magnesium besi aluminium titanium phylloalumosilicate, cronstadite, dan fayalite. Dari data XRD juga menunjukkan bahwa lempung yang digunakan mempunyai kristalinitas yang rendah hal ini ditandai dengan puncak-puncak difraktogram yang tidak tajam seperti pada Gambar 1.

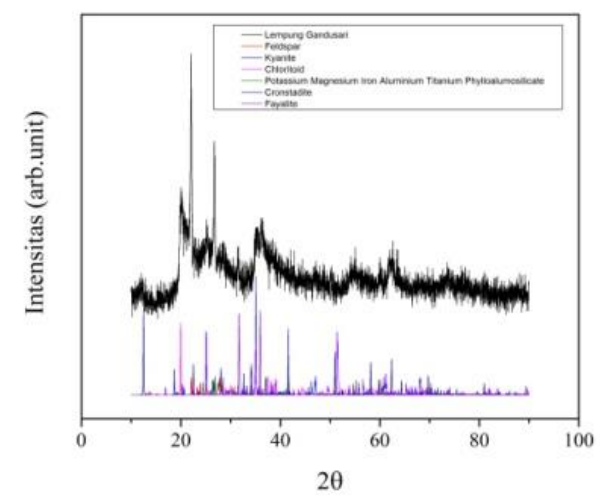

Gambar 1 Hasil XRD Lempung Daerah Gandusari (Mukhlisin, 2013)

\section{Preparasi Lempung Alam dengan Metode Benefisiasi}

Proses benefisiasi lempung alam menggunakan aquades sebagai pelarutnya selama beberapa hari. Lempung alam yang dilarutkan dengan akuades akan terjadi pemisahan menjadi 3 bagian. Senyawa organik dan garam-garam terlarut dalam air berada pada bagian atas, lempung bagian tengah, pasir dan pengotor lainnya dengan berat jenis yang lebih tinggi dari pada lempung berada pada bagian bawah.

Lempung hasil benefisiasi diayak dengan menggunakan ayakan 200 mess untuk mendapatkan ukuran partikel lempung lebih kecil dan seragam sehingga diperoleh luas permukaan lempung yang lebih besar. Hasil ayakan yang lolos dari
200 mesh digunakan sebagai sampel uji dan dikarakterisasi dengan FTIR.

Metode adsorpsi Cr(VI) dilakukan dengan metode Batch yaitu dikontakkan larutan $\mathrm{Cr}(\mathrm{VI})$ dengan lempung alam, $\mathrm{Na}-$ lempung, Na-lempung teraktivasi kimia, Na-lempung teraktivasi fisika, dan Nalempung termodifikasi surfaktan CTAB. Penentuan $\mathrm{Cr}(\mathrm{VI})$ digunakan metode spektrofotometri UV-Vis yang direaksikan larutan $\mathrm{Cr}(\mathrm{VI})$ dengan 1,5-difenilkarbazida sehingga menghasilkan senyawa kompleks yang berwarna ungu.

\section{Adsorpsi $\mathrm{Cr}(\mathrm{VI})$ pada Lempung Alam}

Hasil perhitungan kapasitas adsorpsi didapatkan bahwa lempung alam memiki Qe sebesar 0,0971 mg/g. Hasil adsorpsi pada lempung alam relatif kecil dikarenakan masih terdapat banyak pengotor sehingga kemampuan adsorpsinya masih rendah.

\section{Preparasi Na-lempung dan Adsorpsi Cr(VI) pada Na-Lempung}

Lempung alam yang diperoleh masih memiliki banyak kandungan kation-kation lain, seperti $\mathrm{K}^{+}, \mathrm{Mg}^{2+}$ dan $\mathrm{Ca}^{2+}$ serta memiliki ukuran kation yang tidak seragam sehingga perlu dilakukan penyeragaman ukuran kation yang ada pada daerah interlayer lempung. Penyeragaman ini bertujuan untuk menghasilkan jarak layer yang sama dan meningkatkan kemampuan adsorpsinya.

Tahap pertama menggunakan larutan $\mathrm{NaCl} 1 \mathrm{M}$ yang dilakukan pada suhu $70{ }^{\circ} \mathrm{C}$ selama 24 jam bertujuan untuk mengawali terjadinya reaksi pertukaran kation-kation selain $\mathrm{Na}^{+}$sehingga dapat membuka dan mengaktifkan ruang antar lapis lempung. Pertukaran kation-kation tersebut diharapkan sebagian besar kation-kation selain $\mathrm{Na}^{+}$dapat digantikan oleh kation $\mathrm{Na}^{+}$. Proses pemanasan yang dilakukan bertujuan untuk meningkatkan kemungkinan terjadinya tumbukan antara ion $\mathrm{Na}^{+}$dengan muatan negatif lempung (Wogo, dkk., 2013). 
Tahap kedua menggunakan larutan $\mathrm{NaCl} 6 \mathrm{M}$ dilakukan pada suhu kamar selama 24 jam bertujuan untuk menggantikan kation-kation yang memiliki valensi yang lebih besar dari $\mathrm{Na}^{+}$agar tergantikan oleh kation $\mathrm{Na}^{+}$.

Proses adsorpsi Na-lempung dengan $\mathrm{Cr}(\mathrm{VI})$ diperoleh kapasitas adsorpsi (Qe) sebesar $0,1756 \mathrm{mg} / \mathrm{g}$ dengan peningkatan kapasitas adsorpsi sebesar 7,85\% dari lempung alam. Hasil adsorpsi Na-lempung lebih tinggi dibandingkan dengan lempung alam. Hal ini disebabkan pada permukaan Na-lempung yang bermuatan negatif terdapat kation $\mathrm{Na}^{+}$secara seragam yang dapat meningkatkan daya adsorpsi $\mathrm{Cr}(\mathrm{VI})$.

4. Adsorpsi $\mathrm{Cr}(\mathrm{VI})$ pada Na-Lempung

\section{Teraktivasi Kimia}

Aktivasi lempung secara kimia bertujuan untuk meningkatkan aktivasi lempung sebagai adsorben. Menurut Filayati dan Rusmini (2012), menyatakan bahwa penggunaan larutan $\mathrm{H}_{2} \mathrm{SO}_{4}$ dapat menghilangkan pengotor-pengotor lainnya dari kisi-kisi struktur sehingga secara fisik lempung menjadi aktif.

Proses aktivasi kimia Na-lempung dilakukan perendaman dengan variasi konsentrasi $\mathrm{H}_{2} \mathrm{SO}_{4} 0,5 ; 1,0 ; 1,5$ dan 2,0 M selama 5 jam. Tujuan dari perlakuan dengan variasi konsentrasi untuk mengetahui pengaruh sifat aktif lempung yang dihasilkan terhadap konsentrasi $\mathrm{H}_{2} \mathrm{SO}_{4}$ dalam mengadsorpsi $\mathrm{Cr}(\mathrm{VI})$.

Hasil adsorpsi $\mathrm{Cr}(\mathrm{VI})$ pada Nalempung teraktivasi kimia didapatkan hubungan antara Na-lempung yang diaktivasi dengan variasi konsentrasi $\mathrm{H}_{2} \mathrm{SO}_{4}$ terhadap jumlah $\mathrm{Cr}(\mathrm{VI})$ yang teradsorpsi per satuan berat adsorben (Qe) seperti Tabel 1 dan Gambar 2.

Tabel 1 Hubungan kapasitas adsorpsi (Qe) $\mathrm{Cr}(\mathrm{VI})$ terhadap lempung alam, Na-lempung dan Na-lempung teraktivasi kimia dengan variasi konsentrasi $\mathrm{H}_{2} \mathrm{SO}_{4}$

\begin{tabular}{|c|c|c|c|}
\hline Sampel & $\begin{array}{l}\text { Qe (U1) } \\
(\mathrm{mg} / \mathrm{g})\end{array}$ & $\begin{array}{l}\text { Qe (U2) } \\
\text { (mg/g) }\end{array}$ & $\begin{array}{l}\text { Qe (U3) } \\
\text { (mg/g) }\end{array}$ \\
\hline Lempung alam & 0,0963 & 0,0851 & 0,1098 \\
\hline Na-lempung & 0,1847 & 0,1664 & 0,1756 \\
\hline $\begin{array}{l}\mathrm{Na}- \\
\text { lempung+} \mathrm{H}_{2-} \\
\mathrm{SO}_{4} \mathrm{O}, 5 \mathrm{M} \\
\end{array}$ & $\mathbf{0 , 3 1 5 9}$ & 0,3099 & $\mathbf{0 , 3 0 8 7}$ \\
\hline $\begin{array}{l}\mathrm{Na-} \\
\text { lempung+H } \\
\mathrm{SO}_{4} 1,0 \mathrm{M}\end{array}$ & 0,2832 & 0,2748 & 0,2735 \\
\hline $\begin{array}{l}\mathrm{Na}- \\
\text { lempung+H } \\
\mathrm{SO}_{4} 1,5 \mathrm{M} \\
\end{array}$ & 0,2403 & 0,2429 & 0,2429 \\
\hline $\begin{array}{l}\mathrm{Na}- \\
\text { lempung+H } \\
\mathrm{SO}_{4} 2,0 \mathrm{M}\end{array}$ & 0,2158 & 0,2089 & 0,2130 \\
\hline
\end{tabular}

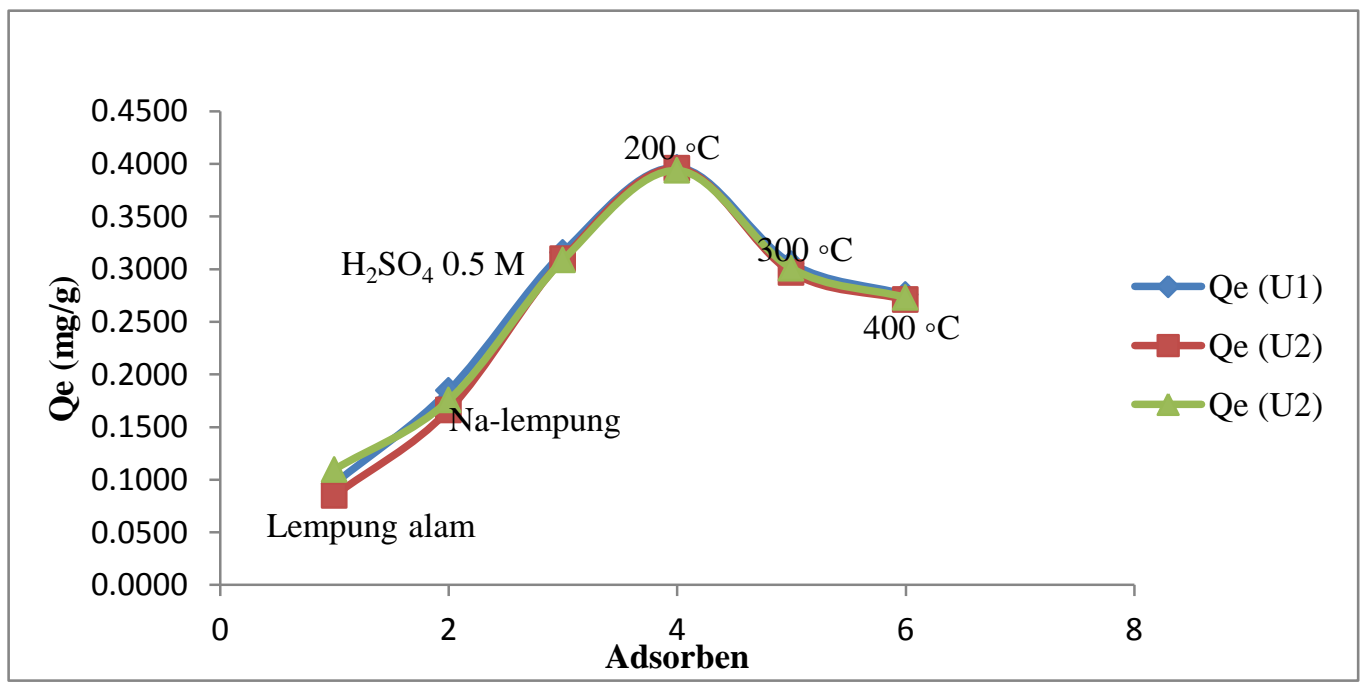

Gambar 2 Hubungan kapasitas adsorpsi (Qe) Cr(VI) terhadap lempung alam, Na-lempung dan Na-lempung teraktivasi kimia dengan variasi konsentrasi $\mathrm{H}_{2} \mathrm{SO}_{4}$ 
Berdasarkan Tabel 1 dan Gambar 2 dapat diamati bahwa dengan adanya penambahan $\mathrm{H}_{2} \mathrm{SO}_{4}$ pada permukaan Nalempung dapat memberikan hasil adsorpsi Cr(VI) yang lebih besar daripada lempung alam dan Na-lempung. Hal ini disebabkan adanya aktivasi asam dapat meningkatkan keasaman yang cukup tinggi dan dapat menghilangkan pengotor-pengotor lainnya dari kisi-kisi struktur sehingga luas permukaan lempung semakin tinggi yang dapat mengadsorpsi $\mathrm{Cr}(\mathrm{VI})$ lebih besar (Akar, dkk., 2009).

Variasi konsentrasi $\mathrm{H}_{2} \mathrm{SO}_{4}$ yang digunakan dalam aktivasi kimia mempengaruhi kapasitas adsorpsi $\mathrm{Cr}(\mathrm{VI})$. Konsentrasi $\mathrm{H}_{2} \mathrm{SO}_{4}$ yang dapat mengadsorpsi anion $\mathrm{Cr}(\mathrm{VI})$ lebih tinggi yaitu $0,5 \mathrm{M}$ yang ditunjukkan nilai Qe sebesar $0,3115 \mathrm{mg} / \mathrm{g}$ dengan peningkatan kapasitas adsorpsi yaitu 21,44\%. Hal ini menunjukkan bahwa proses aktivasi asam dapat menetralkan muatan negatif pada permukaan lempung sehingga sisi aktif lempung bermuatan positif.

Semakin tingginya konsentrasi $\mathrm{H}_{2} \mathrm{SO}_{4}$ 1,0; 1,5; dan 2,0 $\mathrm{M}$ mengalami penurunan adsorpsi $\mathrm{Cr}(\mathrm{VI})$ dibandingkan dengan $\mathrm{H}_{2} \mathrm{SO}_{4} \quad 0,5$ M. Hal ini disebabkan kemungkinan adanya kerusakan dan tidak stabilnya struktur lempung yang disebabkan konsentrasi asam yang terlalu besar.

Tabel 2 Hubungan kapasitas adsorpsi (Qe) Cr(VI) terhadap lempung alam, Na-lempung, Na-lempung teraktivasi kimia terbaik, dan Na-lempung teraktivasi fisika dengan variasi suhu

\begin{tabular}{|c|c|c|c|}
\hline Sampel & $\begin{array}{l}\text { Qe } \\
\text { (U1) } \\
(\mathrm{mg} / \mathrm{g})\end{array}$ & $\begin{array}{l}\text { Qe } \\
\text { (U2) } \\
\text { (mg/g) }\end{array}$ & $\begin{array}{l}\text { Qe } \\
\text { (U3) } \\
\text { (mg/g) }\end{array}$ \\
\hline Lempung alam & 0,0963 & 0,0851 & 0,1098 \\
\hline Na-lempung & 0,1847 & 0,1664 & 0,1756 \\
\hline $\begin{array}{l}\mathrm{Na}- \\
\text { lempung }+\mathrm{H}_{2} \mathrm{SO}_{4} \\
0,5 \mathrm{M}\end{array}$ & 0,3159 & 0,3099 & 0,3087 \\
\hline $\begin{array}{l}\mathrm{Na} \text {-lem }+\mathrm{H}_{2} \mathrm{SO}_{4} \\
0,5 \mathrm{M}+200 \circ \mathrm{C}\end{array}$ & 0,3965 & 0,3958 & 0,3937 \\
\hline $\begin{array}{l}\mathrm{Na}-\mathrm{lem}+\mathrm{H}_{2} \mathrm{SO}_{4} \\
0,5 \mathrm{M}+300 \circ \mathrm{C}\end{array}$ & 0,3053 & 0,2970 & 0,3008 \\
\hline $\begin{array}{l}\mathrm{Na}-\mathrm{lem}+\mathrm{H}_{2} \mathrm{SO}_{4} \\
0,5 \mathrm{M}+400 \circ \mathrm{C}\end{array}$ & 0,2757 & 0,2711 & 0,2731 \\
\hline
\end{tabular}

\section{Adsorpsi $\mathrm{Cr}(\mathrm{VI})$ pada Na-Lempung Teraktivasi Fisika}

Struktur lempung dengan kerangka tiga dimensi menyebabkan lempung memiliki rongga-rongga yang diisi oleh molekul air. Penelitian ini telah melakukan pemanasan lempung yang telah diaktivasi kimia dengan menggunakan tungku listrik pada suhu 200; 300; dan $400{ }^{\circ} \mathrm{C}$ selama 6 jam. Proses pemanasan terhadap lempung bertujuan untuk menguapkan molekul air yang menutupi permukaan lempung sehingga luas permukaan spesifiknya bertambah (Miftahurrohmah, 2011).

Hasil lempung aktivasi fisika variasi suhu dilanjutkan dengan proses adsorpsi terhadap $\mathrm{Cr}(\mathrm{VI})$ sehingga didapatkan hubungan antara lempung aktivasi fisika variasi suhu terhadap jumlah $\mathrm{Cr}(\mathrm{VI})$ yang teradsorpsi per satuan berat adsorben (Qe) seperti pada Tabel 2 dan Gambar 3. Penentuan suhu terbaik adsorpsi terhadap $\mathrm{Cr}(\mathrm{VI})$ bertujuan untuk mengetahui suhu aktivasi fisika dimana larutan $\mathrm{Cr}(\mathrm{VI})$ dapat teradsorpsi secara maksimal oleh adsorben.

Berdasarkan Tabel 2 dan Gambar 3 dapat diketahui bahwa Na-lempung yang teraktivasi kimia terbaik ketika dipanaskan dapat memberikan hasil adsorpsi $\mathrm{Cr}(\mathrm{VI})$ yang lebih besar. Hal ini disebabkan adanya aktivasi fisika dapat menguapkan molekul air yang menutupi permukaan lempung sehingga luas permukaan spesifiknya semakin tinggi.

Pada penelitian ini suhu aktivasi fisika yang mampu mengadsorspsi $\mathrm{Cr}(\mathrm{VI})$ paling besar yaitu suhu $200{ }^{\circ} \mathrm{C}$ yang ditunjukkan nilai Qe $=0,3953 \mathrm{mg} / \mathrm{g}$ dengan peningkatan kapasitas adsorpsi sebesar $29,82 \%$. Hal ini dapat dinyatakan bahwa pada suhu ini terjadi pelepasan air yang berada di interlayer lempung dan ion-ion $\mathrm{H}^{+}$tidak terlepas (Widjaya, 2012). 


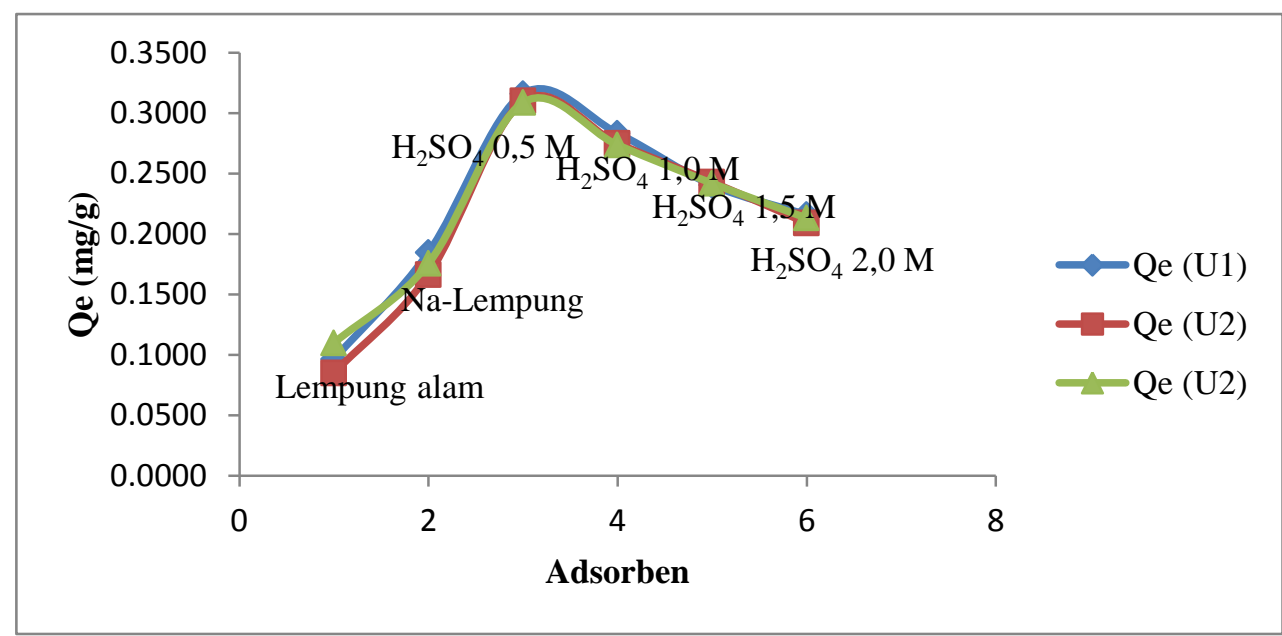

Gambar 3 Hubungan kapasitas adsorpsi (Qe) Cr(VI) terhadap lempung alam, Na-lempung, Na-lempung teraktivasi kimia terbaik, dan Na-lempung teraktivasi fisika dengan variasi suhu

Pada suhu $300-400{ }^{\circ} \mathrm{C}$ kapasitas adsorpsi lempung untuk mengadsorpsi $\mathrm{Cr}(\mathrm{VI})$ mengalami penurunan yang ditunjukkan dengan nilai Qe berturut-turut adalah $0,3010 \mathrm{mg} / \mathrm{g}$ dan $0,2733 \mathrm{mg} / \mathrm{g}$. Hal ini kemungkinan disebabkan pemanasan yang semakin tinggi menyebabkan kerapatan susunan kristal semakin tinggi dan semakin teratur, sehingga lempung semakin tidak reaktif sebagai adsorben. Menurut Wijaya dkk (2002), pemanasan pada suhu $300{ }^{\circ} \mathrm{C}$ terhadap Na-bentonit sudah dapat mengakibatkan rusaknya bidang 001. Lempung akan mengalami kerusakan struktur dan kerusakan antar lapisan pada suhu diatas $250{ }^{\circ} \mathrm{C}$ (sahara, 2011). Ozacar dan sengil (2004), menyatakan bahwa luas permukaan pada alunite meningkat dengan kenaikan suhu kalsinasi (100 - $200{ }^{\circ} \mathrm{C}$ ) sehingga dapat menyerap zat warna dan mengalami penurunan luas permukaan pada suhu kalsinasi $\left(300-400{ }^{\circ} \mathrm{C}\right)$.

\section{Adsorpsi $\mathrm{Cr}(\mathrm{VI})$ pada Na-Lempung Termodifikasi CTAB}

Peningkatan adsorpsi $\mathrm{Cr}(\mathrm{VI})$ dapat dilakukan dengan cara memodifikasi permukaan lempung dengan surfaktan CTAB seperti yang telah dilaporkan oleh Akar, dkk., (2009) bahwa hasil modifikasi lempung dengan surfaktan HDTMA merupakan proses yang paling efektif untuk meningkatkan kapasitas adsorpsi $\mathrm{Cr}(\mathrm{VI})$. Adsorpsi Cr(VI) oleh lempung alam termodifikasi CTAB didasarkan atas konsentrasi CMC-nya (critical micelle concentration) sebesar $1 \mathrm{mM}$. Penelitian ini telah menggunakan konsentrasi CTAB melebihi CMC-nya yaitu 25; 50; 75 dan $100 \mathrm{mM}$. Hal ini bertujuan untuk membentuk lapisan bilayer atau multilayer dengan gugus yang bermuatan positif berada dipermukaan lempung sehingga dengan terbentuk lapisan bilayer maupun multilayer membuat sifat permukaan dari lempung akan berubah yang awalnya bermuatan negatif menjadi bermuatan positif, sehingga kemampuan lempung dalam mengadsorpsi $\mathrm{Cr}(\mathrm{VI})$ yang berupa anion akan lebih maksimal (Plaska, dkk., 2011).

Hasil modifikasi lempung teraktivasi fisika terbaik dengan CTAB dilanjutkan dengan proses adsorpsi $\mathrm{Cr}(\mathrm{VI})$. Hasil adsorpsi dapat diketahui hubungan antara Na-lempung termodifikasi dengan variasi konsentrasi surfaktan CTAB terhadap jumlah $\mathrm{Cr}(\mathrm{VI})$ yang teradsorpsi per satuan berat adsorben (Qe) seperti pada Tabel 3 dan Gambar 4. 
Tabel 3 Hubungan kapasitas adsorpsi (Qe) Cr(VI) terhadap lempung alam, Na-lempung, Na-lempung teraktivasi kimia terbaik, Na-lempung teraktivasi fisika terbaik, dan Na-lempung termodifikasi dengan variasi CTAB

\begin{tabular}{|c|c|c|c|}
\hline Sampel & $\begin{array}{c}\text { Qe } \\
(\mathrm{U1}) \\
(\mathrm{mg} / \mathrm{g})\end{array}$ & $\begin{array}{c}\text { Qe } \\
(\mathrm{U} 2) \\
(\mathrm{mg} / \mathrm{g})\end{array}$ & $\begin{array}{c}\text { Qe } \\
\text { (U3) } \\
\text { (mg/g) }\end{array}$ \\
\hline Lempung alam & 0,0963 & 0,0851 & 0,1098 \\
\hline Na-lempung & 0,1847 & 0,1664 & 0,1756 \\
\hline $\begin{array}{c}\text { Na-lempung+H } \mathrm{H}_{2-} \\
\mathrm{SO}_{4} 0,5 \mathrm{M}\end{array}$ & 0,3159 & 0,3099 & 0,3087 \\
\hline $\begin{array}{c}\mathrm{Na}-\mathrm{lem}+\mathrm{H}_{2} \mathrm{SO}_{4} 0,5 \\
\mathrm{M}+200{ }^{\circ} \mathrm{C}\end{array}$ & 0,3965 & 0,3958 & 0,3937 \\
\hline $\begin{array}{l}\mathrm{Na}-\mathrm{lem}+\mathrm{H}_{2} \mathrm{SO}_{4} \mathrm{0,5} \\
\mathrm{M}+200 \circ \mathrm{C}+25 \mathrm{mM} \\
\end{array}$ & 1,0400 & 1,0454 & 1,0421 \\
\hline $\begin{array}{l}\mathrm{Na}-\mathrm{lem}+\mathrm{H}_{2} \mathrm{SO}_{4} 0,5 \\
\mathrm{M}+200{ }^{\circ} \mathrm{C}+50 \mathrm{mM}\end{array}$ & 1,0333 & 1,0318 & 1,0336 \\
\hline $\begin{array}{l}\mathrm{Na}-\mathrm{lem}+\mathrm{H}_{2} \mathrm{SO}_{4} 0,5 \\
\mathrm{M}+200{ }^{\circ} \mathrm{C}+75 \mathrm{mM}\end{array}$ & 1,0278 & 1,0279 & 1,0281 \\
\hline $\begin{array}{l}\mathrm{Na}-\mathrm{lem}+\mathrm{H}_{2} \mathrm{SO}_{4} 0,5 \\
\mathrm{M}+200^{\circ} \mathrm{C}+100 \mathrm{mM}\end{array}$ & 1,0271 & 1,0256 & 1,0259 \\
\hline
\end{tabular}

Berdasarkan Tabel 3 dan Gambar 4 dapat diketahui bahwa dengan adanya CTAB yang dimodifikasi pada permukaan lempung yang teraktivasi kimia terbaik dan fisika terbaik dapat memberikan hasil adsorpsi $\mathrm{Cr}(\mathrm{VI})$ yang lebih besar dari pada lempung alam tanpa dimodifikasi dengan
CTAB. Hal ini disebabkan adanya surfaktan CTAB yang berada di permukaan lempung mengadsorpsi $\mathrm{Cr}(\mathrm{VI})$ lebih besar.

Mekanisme adsorpsi $\mathrm{Cr}(\mathrm{VI})$ pada lempung alam termodifikasi CTAB diatas CMC-nya sebagai berikut (Thanos, dkk., 2012):

Lempung- $(\mathrm{CTA})_{2}{ }^{+}-\mathrm{Br}^{-}+\mathrm{HCrO}_{4}^{-} \leftrightarrow$ Lempung- $(\mathrm{CTAB})_{2} \mathrm{HCrO}_{4}+\mathrm{Br}^{-}$

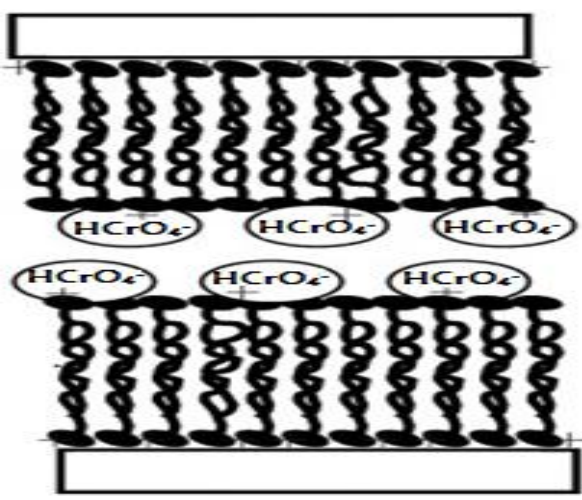

Gambar 5 Ilustrasi Adsorpsi $\mathrm{Cr}(\mathrm{VI})$ dalam bentuk $\mathrm{HCrO}_{4}{ }^{-}$pada lempung termodifikasi CTAB di atas CMC-nya

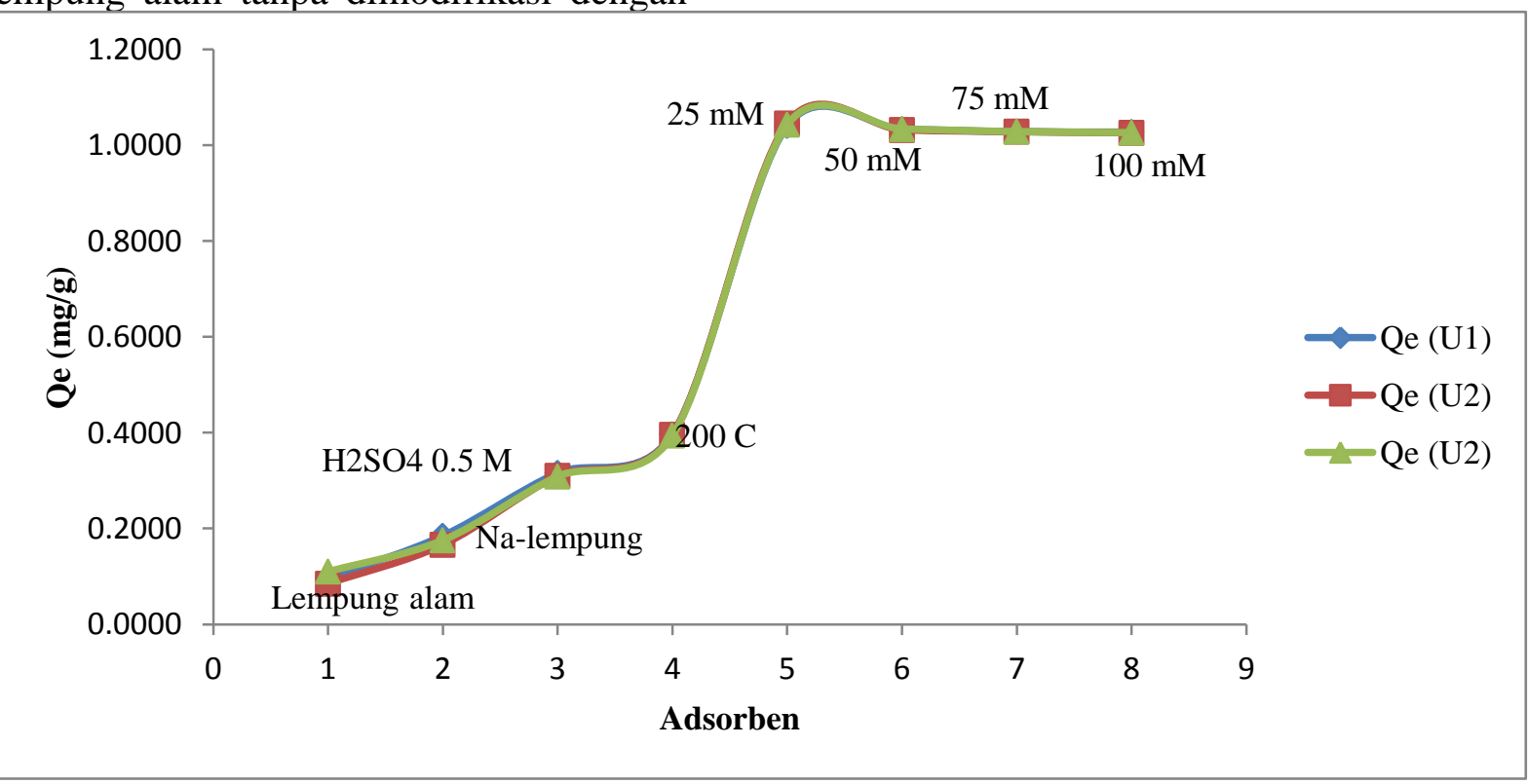

Gambar 4 Hubungan kapasitas adsorpsi (Qe) Cr(VI) terhadap lempung alam, lempung teraktivasi kimia terbaik, lempung teraktivasi fisika terbaik, dan lempung termodifikasi dengan variasi CTAB 
Proses adsorpsi Cr(VI) pada lempung yang termodifikasi surfaktan CTAB di atas CMC-nya melibatkan pertukaran anion antara ion bromida dari CTAB dengan spesies ion $\mathrm{Cr}(\mathrm{VI})$, sehingga semakin banyak $\mathrm{Cr}(\mathrm{VI})$ yang teradsorpsi (Thanos, dkk., 2012)

\section{Karakterisasi FTIR}

Karakterisasi FTIR bertujuan untuk mengetahui adanya gugus-gugus fungsional utama lempung. Spektra lempung untuk daerah inframerah dibagi dalam dua kelompok daerah frekuensi yaitu daerah antara 4000 sampai $3000 \mathrm{~cm}^{-1}$ merupakan getaran regang dari air yang terserap atau gugus $\mathrm{OH}$ oktahedral. Daerah 1400 sampai $800 \mathrm{~cm}^{-1}$ yang disebabkan getaran Al-OH atau Si-O.

Penggunaan FTIR dilakukan pada lempung alam sebelum dan sesudah aktivasi serta modifikasi permukaanya dengan surfaktan CTAB untuk mengetahui adanya perubahan-perubahan gugus fungsional utama lempung yaitu Si-O/AlO. Hasil karakteristik FTIR seperti pada Gambar 6.

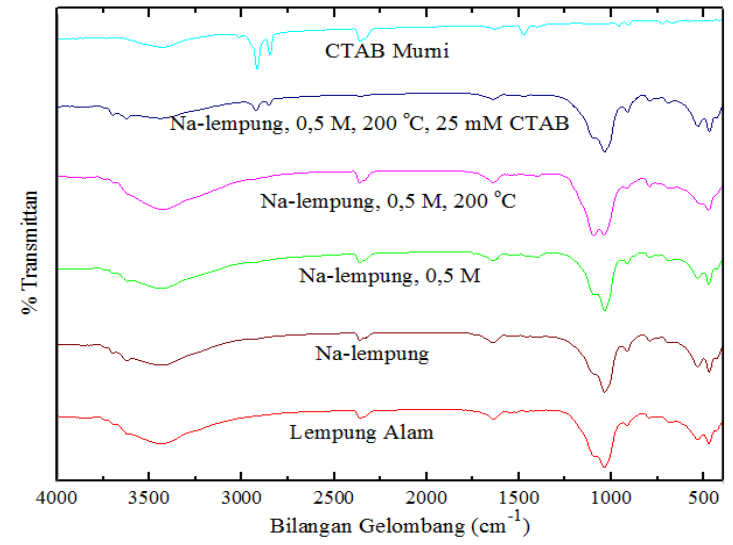

Gambar 6 Spektra IR lempung alam, Na-lempung, Na-lempung teraktivasi kimia terbaik, Nalempung teraktivasi fisika terbaik, dan Na-lempung termodifikasi CTAB terbaik

Berdasarkan Gambar 6 dapat dinyatakan bahwa selama perlakuan aktivasi kimia, fisika dan modifikasi permukaannya dengan surfaktan CTAB tidak mengalami perubahan/kerusakan struktur lempung. Pada perlakuan modifikasi permukaan lempung terdapat spektra baru pada panjang gelombang 2851 dan $2920 \mathrm{~cm}^{-1}$ yang menunjukkan adanya C-H stretching (Plaska,dkk., 2012).

\section{KESIMPULAN DAN SARAN Kesimpulan}

Perlakuan aktivasi dan modifikasi pada lempung alam dapat meningkatkan kemampuan adsorpsi $\mathrm{Cr}(\mathrm{VI})$ lebih besar yang ditunjukkan dengan nilai Qe (kapasitas adsorpsi). Kapasitas adsorpsi lempung alam memiliki Qe $=0,0971 \mathrm{mg} / \mathrm{g}$ dan Na-lempung bernilai Qe $=0,1756$ $\mathrm{mg} / \mathrm{g}$ dengan peningkatan sebesar 7,85\% dari lempung alam. Lempung teraktivasi $\mathrm{H}_{2} \mathrm{SO}_{4} \quad 0,5 \quad \mathrm{M}$ mengalami peningkatan adsorpsi sebesar 21,44\% dengan nilai Qe $=0,3115 \mathrm{mg} / \mathrm{g}$. Lempung alam teraktivasi fisika setelah diaktivasi kimia terbaik diperoleh pada suhu $200{ }^{\circ} \mathrm{C}$ dengan nilai $\mathrm{Qe}=0,3953 \mathrm{mg} / \mathrm{g}$ yang menunjukkan peningkatan adsorpsi sebesar 29,82 \%. Sedangkan konsentrasi surfaktan CTAB terbaik pada lempung alam termodifikasi diperoleh pada konsentrasi CTAB $25 \mathrm{mM}$ dengan nilai Qe terbesar yaitu $1,0425 \mathrm{mg} / \mathrm{g}$ yang ditunjukkan peningkatan adsorpsi sebesar 94,54\%.

\section{Saran}

Penelitian lanjutan yang disarankan untuk menyempurnakan penelitian ini adalah dengan menentukan persamaan isotermis adsorpsi dan dengan menambahkan karakterisasi Na-lempung, Na-lempung teraktivasi kimia, Nalempung teraktivasi fisika serta $\mathrm{Na}-$ lempung termodifikasi CTAB menggunakan XRD.

\section{DAFTAR PUSTAKA}

Abdulloh. 2004. Evaluasi Teknik Uji Geser dan Uji Tekanan Dalam Kajian Pengaruh Kadar Aor dan Penambahan Zat Limbun Terhadap Karakteristik Plastisitas Lempung Asal Dsn. Pandisari Kec. Kuterejo Kab. Mojokerto. Tesis Tidak diterbitkan. 
Bandung: Departemen Kimia FMIPA ITB.

Akar, S.T., Yetimoglu, Y., dan Gedikbey, T. 2009. Removal of Chromium(VI) Ions from Aqueous Solutions by Using Turkish Montmorillonite Clay: Effect of Activation and Modification. Science Direct pp 97-108. Turkey: Eskisehir Osmangazi University.

Bhattacharrya, K.G. dan Gupta, S.S., 2006, Kaolinite, Montmorillonite, and Their Modified Derivatives as Adsorbents for Removal of $\mathrm{Cu}(\mathrm{II})$ from a Aqueous Solution, Separation and Purification Technology,50, pp. 388-397 Cotton dan Wilkinson, 1989.

Khenifi, A., Bouberka, Z., Sekrane, F dan Kameche, M. 2007. Adsorption Study of An Industrial Dye by an Organic Clay. Algeria: Physico-chemical Material Laboratory, Chemistry Department Faculty of Science

Miftahurrohmah. 2011. Aktivasi dan Karakterisasi Lempung Alam BesitoKudus untuk Adsorben Zat Warna Congo Red. Tesis. Yogyakarta: Jurusan Kimia FMIPA UGM

Mukhlisin. 2013. Karakterisasi Sifat Fisikokimia Lempung dari Daerah Kecamatan Gandusari dan Kampak Kabupaten Trenggalek. Skripsi. Malang: Jurusan Kimia Fakultas Sains dan Teknologi Universitas Islam Negeri Malang

Ozacar, M dan Sengil, I.A. 2006. The Role of Clay Fractions of Marly Soils on Their Post Stabilization Minimize Contact Time. Environmental Management 80, 372-379

Patri, N. 2012. Adsorpsi ion Cr(III) dan $\mathrm{Cr}(\mathrm{VI}) \quad$ Menggunakan Bentonit
Termodifikasi Oksida Besi. Skripsi. Bogor: Jurusan Kimia FMIPA ITB

Plaska, A.G., Majdan, M., Pikus, S., dan Sternik, D. 2012. Simultaneous Adsorpsi of Chromium (VI) and Phenol on Natural Red Clay Modified by HDTMA. Poland: Faculty of Chemistry, Maria Curie Sklodowska University, pl. M. C, Sidodowskiej 2, 20-031

Sahara, E. 2011. Regenerasi Lempung Bentonit dengan $\mathrm{NH}_{4}{ }^{+}$Jenuh yang Diaktivasi Panas dan Daya Adsorpsinya Terhadap Cr(III. Jurnal kimia 5(1) : 81-87. Bukit Jimbaran: Lab Kim. Analitik Jur. Kimia FMIPA Universitas Udayana

Suarya, P,. 2008. Adsorpsi Pengotor Minyak Daun Cengkeh oleh Lempung Teraktivasi Asam. Jurnal Kimia 2(1), 19-24. Bukit Jimbaran: Jurusan Kimia FMIPA Universitas Udayana

Widjaya, R.R. 2012. Bentonit Pilarisasi Cr dan Zeolit HZSM-5 Sebagai Katalis pada Proses Konversi Ethanol menjadi Biogasolin. Skripsi. Depok: Universitas Indonesia

Wijaya, K., Pratiwi, S.A., Sudiono, S., dan Nurahmi, E. 2002. Studi Kestabilan Termal dan Asam Lempung Bentonit. Journal of Chemistry 2(1), 22-29. Yogyakarta: Jurusan Kimia FMIPA UGM

Wogo, H. E., Nitbani, F.O., dan Tjitda P.J.P. 2013. Sintesis Lempung Terinterkalasi Anilin dan Pemanfaatannya sebagai Adsorben Fenol. Sains dan Terapan Kimia, vol.7. No. 1. Kupang: Jurusan Kimia FST Universitas Nusa Cendana 